\title{
Melanoma arising in a Giant congenital melanocytic nevus: two case reports
}

\author{
Tatiana S. Belysheva', Yana V. Vishnevskaya ${ }^{1}$, Tatiana V. Nasedkina ${ }^{1,2}$, Marina A. Emelyanova ${ }^{2}$, Ivan S. Abramov ${ }^{1,2}$, \\ Kristina V. Orlova ${ }^{1 *}$ (D), Ludmila N. Lubchenko ${ }^{1}$, Igor A. Utyashev ${ }^{1}$, Marina B. Doroshenko ${ }^{1}$, Lev V. Demidov ${ }^{1}$ and \\ Mamed D. Aliev ${ }^{1}$
}

\begin{abstract}
Background: A giant congenital melanocytic nevus (GCMN) is found in $0.1 \%$ of live-born infants. If present, the lesion has a chance of about $6 \%$ to develop into malignant melanoma. Both children and adults can be affected by malignant melanoma arising in a giant congenital nevus. Up to $95 \%$ of GCMNs harbor NRAS mutations, and mutations in the BRAF, MC1R, TP53, and GNAQ genes have also been described. The individualization of therapy is required, but diagnostic and prognostic criteria remain controversial.

Case presentations: We report two cases: 1) melanoma arising in a giant congenital nevus during the first month of life complicated with neurocutaneous melanosis (NCM), and 2) melanoma arising in a giant congenital nevus during the first 6 months of life. Pathology, immunohistochemistry, and genetic analyses of tumor tissue were performed. The first case revealed only a non-pathogenic P72R polymorphism of the TP53 gene in the homozygote condition. For the second case, a Q61K mutation was detected in the NRAS gene.

Conclusion: Malignant melanoma associated with GCMN is rare and therefore poorly understood. Outcomes have been linked to the stage at diagnosis, but no additional pathological prognostic factors have been identified. The most frequent genetic event in giant CMNs is NRAS mutations, which was discovered in one of our cases. To accumulate evidence to improve disease prognosis and outcomes, children with congenital melanocytic nevus should be included in a systemic follow-up study from birth.
\end{abstract}

Keywords: Giant congenital melanocytic nevus, Melanoma, Neurocutaneous melanosis, Genetic analysis, NRAS mutation, Infants

\section{Background}

Malignant melanoma is a rare tumor during childhood and accounts for up to $0.9 \%$ of all pediatric malignancies $[1,2]$. A congenital melanocytic nevus $(\mathrm{CMN})$ is clinically defined as a melanocytic lesion that is present at birth or develops during infancy from preexistent melanocytes [3-5]. CMNs typically affect the trunk and proximal parts of the limbs, scalp, and neck, but might involve any other skin surface. Congenital melanocytic nevi are usually classified by size. The risk of developing melanoma over a CMN is believed to be directly proportional to the size of the nevus and varies from 2.6 to $4.9 \%$ for small and medium nevi and from 6 to

\footnotetext{
* Correspondence: krisman03@gmail.com

${ }^{1}$ Federal State Budgetary Institution, "N.N. Blokhin Medical Research Center of Oncology" of the Ministry of Health of the Russian Federation, 115478 Kashirskoye shosse, 24, Moscow, Russian Federation

Full list of author information is available at the end of the article
}

$20 \%$ for giant nevi [6]. There has been controversy about the incidence of melanoma and thus the clinical management of CMN, which is partly due to the difficulties of histological diagnosis and partly due to publishing bias towards cases of malignancy.

Giant congenital melanocytic nevus (GCMN) is usually defined as a melanocytic lesion that is present at birth and will reach a diameter of $\geq 20 \mathrm{~cm}$ in adulthood. Its incidence is estimated as $<1: 20,000$ newborns, of which about $6 \%$ develop melanoma at the site of the nevus. GCMN is the main risk factor for the development of melanoma in childhood. Currently, there is tremendous uncertainty regarding how GCMNs should be treated. The standard approach is based on two main considerations: (1) obtaining an acceptable cosmetic result to decrease the psychosocial inconvenience to the patient and (2) minimizing the risk of

(C) The Author(s). 2019 Open Access This article is distributed under the terms of the Creative Commons Attribution 4.0 International License (http://creativecommons.org/licenses/by/4.0/), which permits unrestricted use, distribution, and 
malignancy. However, there are descriptions of clinical cases where melanoma developed after the removal of a giant nevus [7] and in old age [8].

GCMN usually occurs sporadically $[9,10]$, but rare familial cases have also been reported [11, 12]. A report of monozygotic twins discordant for GCMN suggests that a postzygotic event might be involved [10]. The etiology and pathogenesis of GCMN are not fully understood. Various mechanisms have been posited, such as defects in neural crest development [13-15], activating mutations leading to uncontrolled melanocyte proliferation $[16,17]$, cutaneous mosaicism, and paradominant inheritance [12]. Melanoblasts originate from the neural crest cells, and their proliferation, migration, and differentiation are regulated by a complex network of interacting genes. Mutations in this network, such as in genes MITF and KIT and probably in the hepatocyte growth factor/c-Met signaling pathway, might deregulate the pigmentation system during embryogenesis, resulting in various congenital disorders [12].

Another gene network that controls the proliferation of melanocytes is the RAS/RAF/MAPK signaling pathway. Various activating mutations in this pathway have been identified, which involve the genes NRAS [16, 18], BRAF [1820], and GNAQ [21]. Postzygotic mutations in the NRAS gene are thought to be responsible for $\mathrm{CMN}$ formation in $80 \%$ of cases because the same mutation is found in different cutaneous lesions from the same individual and in affected neurological and malignant tissue. The NRAS mutations often result in an amino acid substitution in codon 61 . The BRAF V600E mutation can also be found but in no more than one lesion of the same patient and therefore cannot be assigned as causal [22]. Additionally, mutations in MC1R $[18,23]$ and TP53 [18] have been identified in CMN and might be involved in its formation. The presence of $B R A F$ or NRAS mutations does not confer an increased risk of malignant transformation [21], and further mutations are required to cause melanoma formation in a CMN [22].

Both children and adults can be affected by malignant melanoma arising in GCMN, which has a bimodal distribution with around $70 \%$ of cases occurring in childhood. Differential diagnosis should be done to distinguish between malignant and benign proliferations that may resemble malignant melanoma but usually lack progressive growth or ulceration. Benign proliferations within $\mathrm{CMN}$ are common and primarily arise in large or multiple nevi, although not exclusively. Knowledge of their features is helpful in monitoring for malignancy. In addition to proliferative nodules, GCMN are often associated with "satellite nevi," which are smaller CMN that are present at birth or arise months to years later.

Only several large institutions have experience in treating children (from birth to 1 year old) with malignant melanoma. The outcomes described were linked to the stage at diagnosis and the presence of severe complications, such as neurocutaneous melanosis or melanoma in the central nervous system (CNS) [24]. Neurocutaneous melanosis (NCM) is a rare syndrome that is characterized by benign or malignant proliferated melanocytic nodules in the CNS and is associated with the presence of congenital melanocytic lesions.

To date, no absolute guidelines to treat the GCMN have been established, and therefore, the subject remains one of the most controversial issues in dermatologic surgery and dermatologic oncology. We describe two rare cases of CMN: a case of melanoma arising in GCMN during the first month of life complicated with NCM, and another case arising in GCMN during the first 6 months of life. The clinical, pathological, and genetic characteristics of these patients are described, which provide evidence about this rare disease and generate data needed for the establishment of individual diagnostic and prognostic criteria.

\section{Case presentations Case 1}

Patient $\mathrm{M}$ was referred to us at the age of 22 days. Written informed consent was obtained from the parents of the patient for publication of the case report and any accompanying images. This patient had skin phototype II according to the Fitzpatrick scale. The boy was born during the 37th week of pregnancy. The pregnancy had no complications, and there was no family history of melanoma or other types of cancer. The child's parents reported a giant pigmented mole on the child's skin that covered parts of the back and buttocks and extended to part of the pubis and the scrotum, which was revealed at birth. Within the pigmented mole, the parents also noted an anomalously formed center with a wet and bleeding surface in the lumbar-sacral part (Fig. 1).

Upon clinical examination, a giant pigment mole (larger than $20 \mathrm{~cm}$ ) was observed in mostly the dorsal part of the body, which was partially covered with hair with irregular pigmentation. The colors varied from pink to dark-brown or black. A rapidly growing nodule with irregular forms $(3.5 \times 3.7 \mathrm{~cm})$ of black color and ulceration was detected in the lumbar-sacral part (Fig. 1b). There were single satellites on the hair-covered part of the head, body, and extremities. A dermatoscopic exam was performed. Based on anamnesis, clinical investigation, and dermatoscopy, we diagnosed a giant congenital nevus with satellites, together with congenital malignant melanoma of the lumbar-sacral part with ulceration. Complete ultrasound examination of the lymph nodes, abdomen, retroperitoneal part, and pelvis was performed, as well as X-rays of the chest. Excision biopsy with local tissue plastic was performed under anesthesia in July 2015. Histopathology revealed a nodular epithelioid and nevoid-cell pigment-containing melanoma (Fig. 2a), which arose in the congenital nevus with 1 mitosis/ $\mathrm{mm}^{2}$, ulceration (Fig. 2b), vertical growth phase, Clark invasion level 3, and Breslow thickness of $1.5 \mathrm{~mm}$. There were 


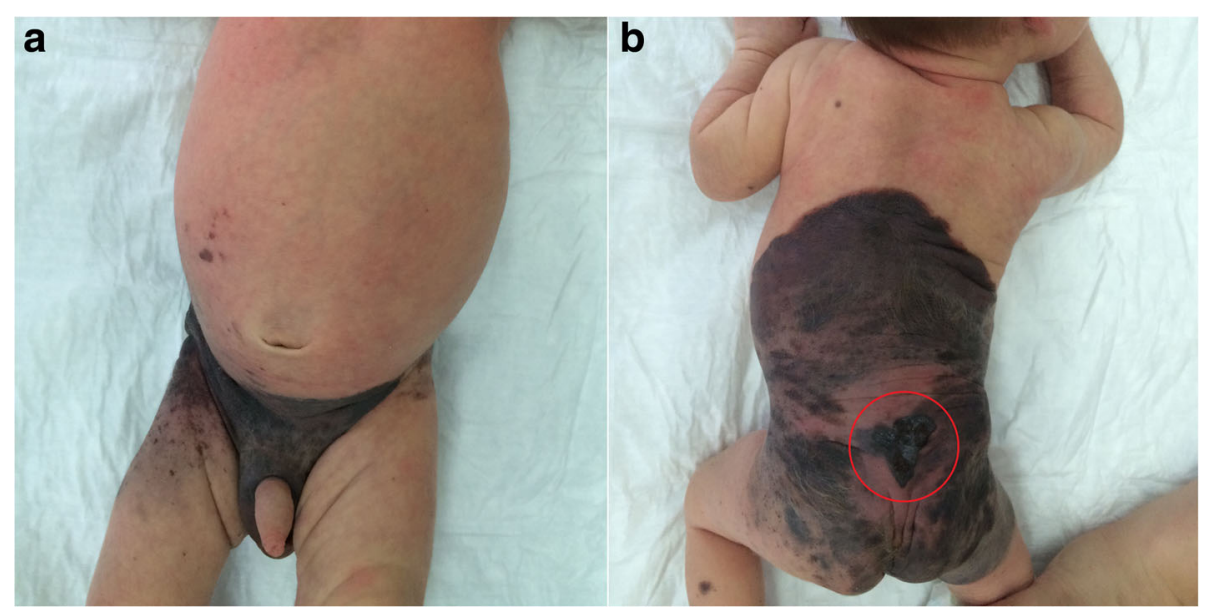

Fig. 1 Patient M at 22 days old before surgery. a Front and (b) back views. A nodule was diagnosed in the lumbar-sacral part (marked with a red circle)

no symptoms of vessel invasion. Immunohistochemistry was performed to detect the expression of melanocyte markers (Melan A, HMB 45), and the Ki67 proliferation index of the tumor cells was $20-30 \%$ (Fig. 3).

Genetic analysis of tumor tissue was performed using a diagnostic biochip (EIMB RAS, Russia) for the detection of most common somatic mutations in the BRAF, NRAS, KIT, GNAQ, GNA11, MAP2K1, and MAP2K2 genes [25]. No mutations in the above-mentioned genes were detected. Additionally, next-generation sequencing was used for exon analysis of the NRAS, PDGFRA, KIT, RASA1, RAC1, MET, BRAF, PTEN, AKT1, MAP2K1, MAP2K2, TP53, and TERT genes. To identify germinal mutations, exons of the $C D K N 2 A$ gene were analyzed by Sanger sequencing. As a result, only Arg/Arg polymorphism at codon 72 of the TP53 gene, which is not pathogenic, was revealed.

The presence of melanin in the brain structures was revealed by magnetic resonance imaging (MRI) of the whole body. The MRI of the melanin centers did not indicate melanoma metastasis and was typical for NCM (Fig. 4). This finding illustrates the importance of carrying out MRI for children with giant congenital nevus. The patient had no focal neurological symptoms such as seizures and no signs and symptoms of raised intracranial pressure. Based on pathology data and full examination of the patient, we made a diagnosis of melanoma T2bN0M0 stage IIA plus NCM, and dynamic observation was recommended. At present (June 2018), the child is under observation and shows no symptoms of disease progression. The focal leptomeningeal deposits are stable.

\section{Case 2}

Patient $\mathrm{L}$ was 5 months old at referral. Written informed consent was obtained for publication of the case report with accompanying images. The patient's skin was Fitzpatrick phototype II. The patient's mother came with

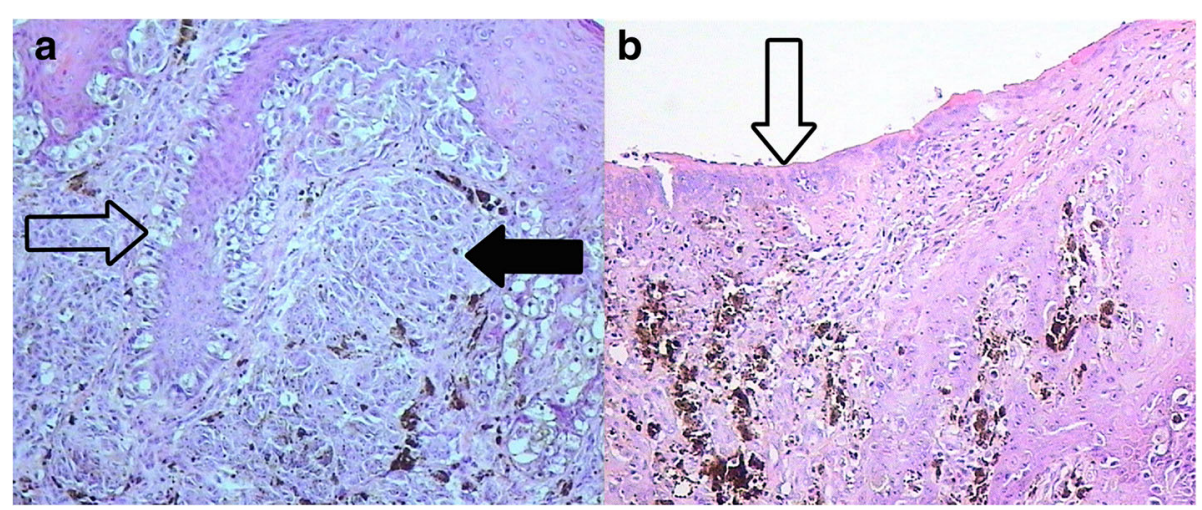

Fig. 2 Cutaneous melanoma; hematoxylin and eosin staining. a Nodular melanoma. Polymorphous melanocytes in the basal layer of the epidermis (transparent arrow) in the dermis in the condition of nested clusters and fields (black arrow), $\times 10$ magnification. $\mathbf{b}$ Ulceration on the surface of the tumor (arrow), $\times 10$ magnification 


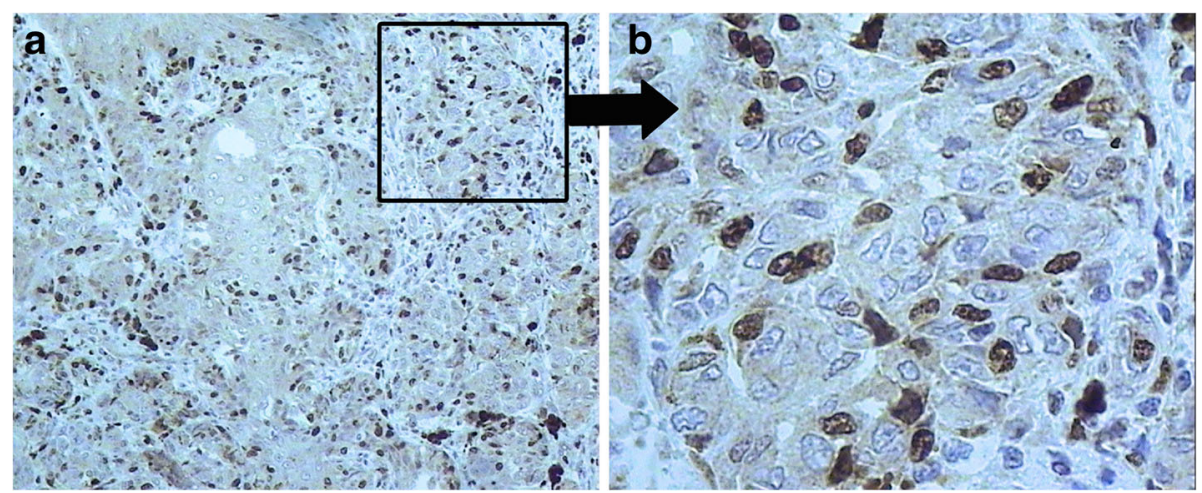

Fig. 3 Cutaneous melanoma; immunohistochemical staining of Ki-67. $\mathbf{a} \times 10$ and $(\mathbf{b}) \times 40$ magnifications

complaints about a giant pigmented mole that was present from birth. It was mostly located in an occipital part of the child's head and extended to the back part of the neck, upper part of the shoulders, and the back and chest. There were also numerous isolated pigment masses on the child's body and limbs (Fig. 5). The boy was born during the 39th week of pregnancy. There was a giant pigmented mole (larger than $20 \mathrm{~cm}$ ) that was partially covered with hair and characterized by irregular pigmentation with colors from pink and light-brown to grey-black. The mole was seen mostly on the upper back and partially spread to the chest, back of the neck, and crown of the head. A large, newly pigmented neoplasm was detected on the back of the neck.

The dermatoscopic picture was not informative. Based on anamnesis and a clinical examination, we made a diagnosis of giant congenital nevus with satellites and congenital cutaneous melanoma of the back of the neck. Anesthetic was provided, and diagnostic excision biopsy was performed in October 2014. Ultrasound was used to examine the peripheral lymph nodes, abdomen, and retroperitoneal and pelvic organs. A CT scan of the chest and MRI of the neck were also performed. Ultrasound examination and MRI of the neck with intravenous contrast identified the metastatic satellite. Histopathology shows an epithelioid cell melanoma with 2 mitoses $/ \mathrm{mm}^{2}$, satellites, and no ulceration or vessel invasion. The Breslow thickness without satellites was $2 \mathrm{~mm}$. A distinctly shaped tumor node (indicated by an arrow in Fig. 6) was detected in the subcutaneous tissue and identified as a melanoma satellite (Fig. 6).

Genetic analysis of the tumor was performed using a diagnostic biochip for the detection of somatic mutations in the BRAF, NRAS, KIT, GNAQ, GNA11, MAP2K1, and $M A P 2 K 2$ genes, Sanger sequencing for searching germinal mutations in the CDKN2A gene. Eventually, a Q61K mutation was revealed in the NRAS gene.

Based on the pathology report and whole-body examination, we made a diagnosis of melanoma T2aN2cM0 stage IIIB. Observation was recommended because of the patient's age. The child is currently (July 2018) under

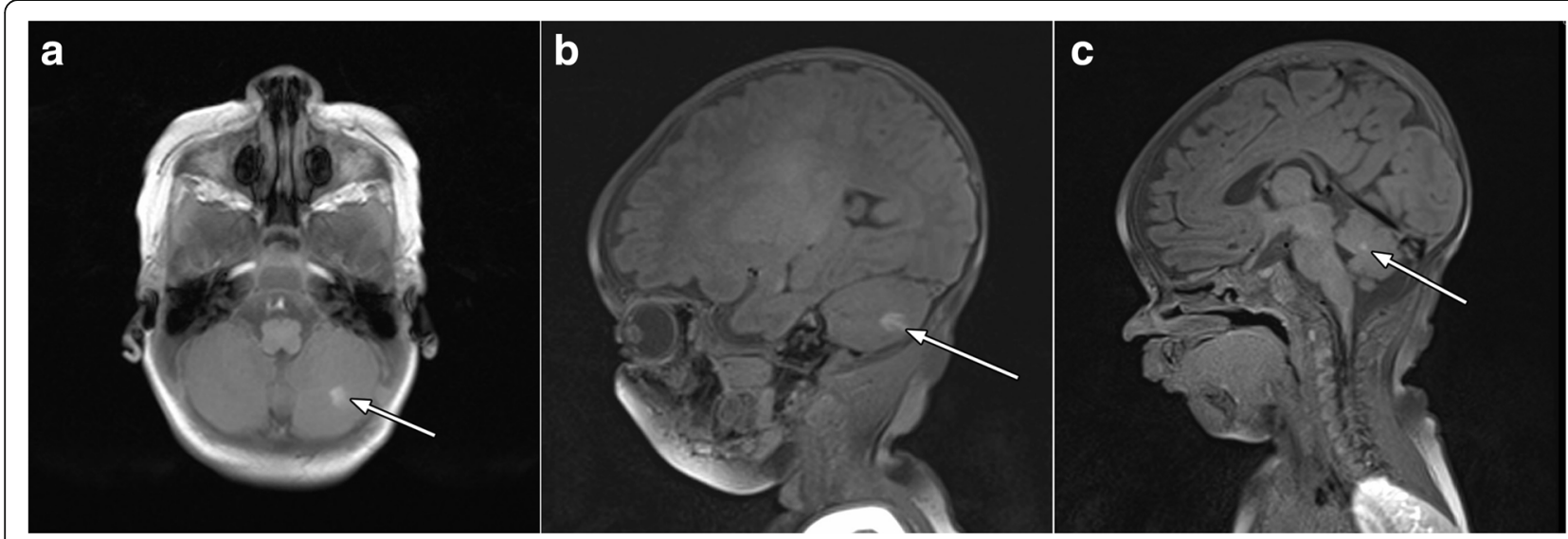

Fig. 4 Magnetic resonance imaging shows the presence of melanin in the structure of the brain. a Postcontrast axial T1-weighted (W) MRI and (b) postcontrast sagittal T1W image with focus on the altered MR signal in the left hemisphere of the cerebellum is determined. c Sagittal T1W image with focus on the abnormal MR signal on the cerebral pia mater of the cerebellum. The imaging findings described were diagnostic for neurocutaneous melanosis 


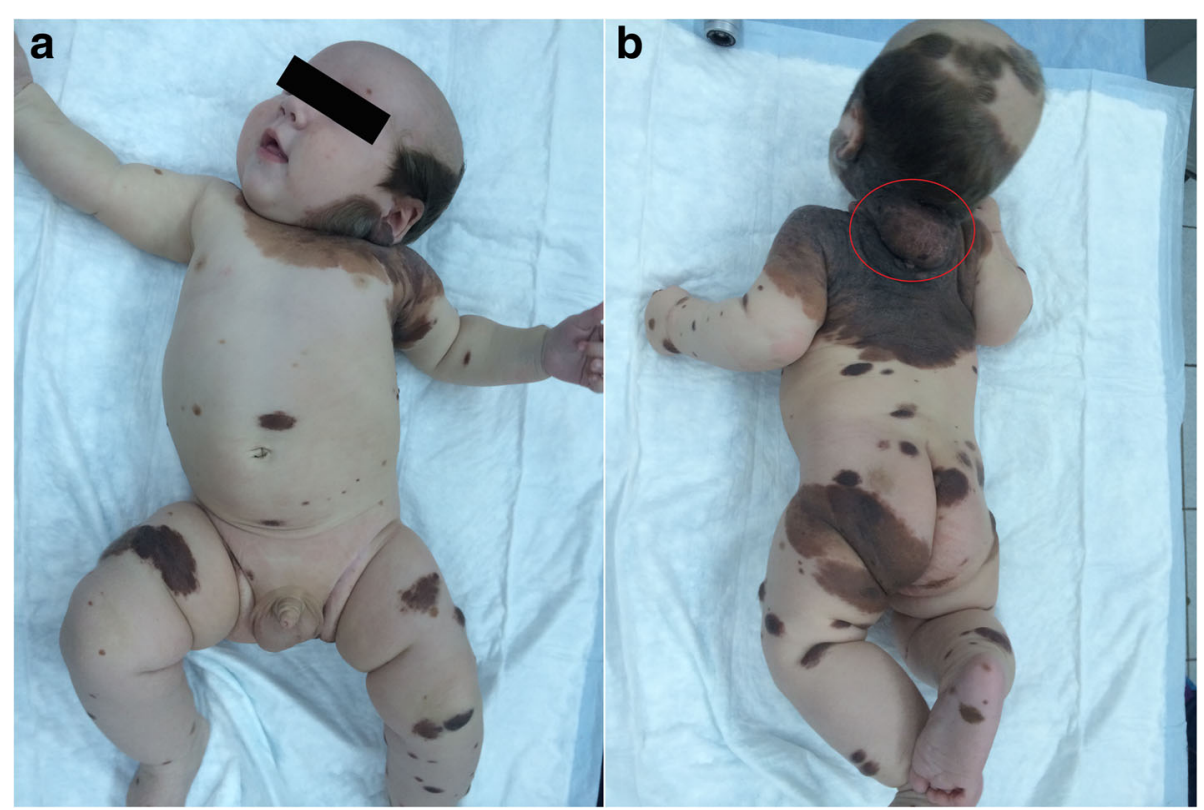

Fig. 5 Patient $L$ at 5 months old before treatment. a Front view and (b) back view

observation and shows no symptoms of disease progression.

\section{Discussion}

Malignant melanoma is a rare neoplasm in pediatric patients, but children with CMN have a greater risk of melanoma. The size and location of the CMN and its association with multiple satellite nevi also seem to influence malignization and melanoma development. The risk of developing melanoma over a CMN is believed to be directly proportional to the size of the nevus [6]. According to the literature, $67 \%$ of cases have revealed primary melanoma within the nevus, with $14 \%$ showing metastatic melanoma with an unknown primary site and $8 \%$ showing extracutaneous melanoma [26]. Cutaneous melanoma arising in the CMN usually presents as a new nodule or lump that mainly arises in the deeper dermis or subcutaneous tissue $[27,28]$. Most of the clinical reports (up to 90\%) indicate malignant

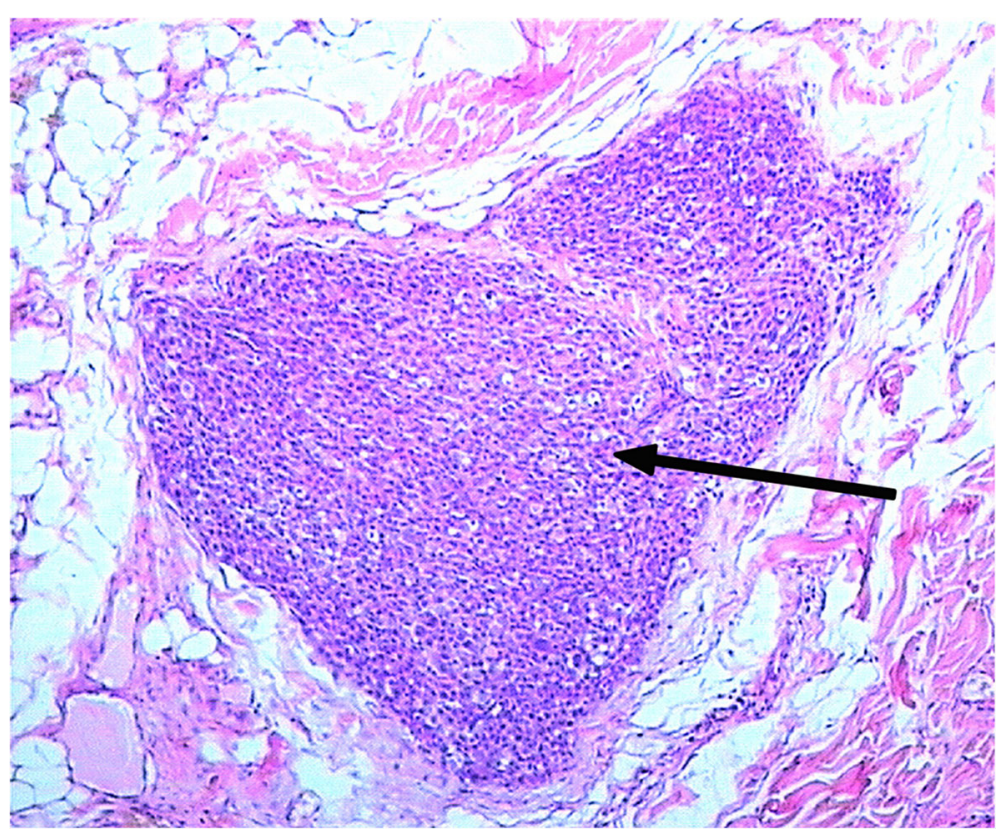

Fig. 6 A melanoma satellite in the subcutaneous tissue. Hematoxylin and eosin staining, $\times 5$ magnification 
melanoma on the trunk [29]. Only isolated clinical cases or small series of cases are described, which confirm the rare occurrence and necessity of accumulating data and clinical experience [30]. Table 1 summarizes information about cutaneous melanoma cases arising in GCMN. Some of the reports contain only clinical and dermatoscopic characteristics with no detailed pathological and genetic data [8, 30, 31].

We describe two cases of melanoma arising in a giant $\mathrm{CMN}$ as a new growing nodule and provide detailed clinical, dermatoscopic, pathological, and genetic analyses. When a diagnosis of cutaneous melanoma is suspected in a CMN patient, a biopsy should be performed (through excision if possible) with a detailed histopathological examination by at least two experts. Melanomas arising from giant congenital nevus predominantly develop from dermal melanocytes, as opposed to the melanomas emerging from small and medium nevi, which originate from the epidermis [3].

Clark reported that diagnostic problems at the histological level are due to the complex cellular composition of some of the nodular overgrowths occurring in congenital melanocytic lesions. Four major histological patterns of proliferation have been observed in CMN at birth or in the neonatal period: 1) simulants of superficial spreading melanoma with increased numbers of large epithelioid melanocytes; 2) simulants of nodular melanoma with black nodules of epithelioid melanocytes; 3 ) nodular proliferative neurocristic hamartomas; and 4) biologic malignant melanomas, which are mostly characterized by small "blastic" pleomorphic melanocytes with a high mitotic rate. Clark believed that the true melanomas with metastatic potential usually develop after the neonatal period [32]. Our cases confirm Clark's findings because both children are now under observation without signs of disease progression despite the stage, early age of melanoma development, and subsequent surgical treatment.

Histological examination is the standard for the diagnosis of malignant melanoma and was performed in both of our cases. In the first case, the histopathology showed a nodular type of melanoma (Fig. 2a), which arose in the congenital nevus background with 1 mitosis $/ \mathrm{mm}^{2}$, ulceration (Fig. 2b), vertical growth phase, Clark invasion level 3, and Breslow

Table 1 Clinical and genetic features of patients with congenital melanocytic naevus (CMN) and melanoma: literature data and own experience

\begin{tabular}{|c|c|c|c|c|c|c|c|}
\hline $\begin{array}{l}\text { Author, } \\
\text { Case № }\end{array}$ & Sex & $\begin{array}{l}\text { Age at } \\
\text { diagnosis } \\
\text { (years) }\end{array}$ & $\begin{array}{l}\text { Outcome/ } \\
\text { time after } \\
\text { diagnosis }\end{array}$ & $\begin{array}{l}\text { MRI } \\
\text { CNS }\end{array}$ & Primary melanoma site & $\begin{array}{l}\text { Tissue for } \\
\text { genetic } \\
\text { analysis }\end{array}$ & Genetics \\
\hline \multicolumn{8}{|c|}{ Literature data } \\
\hline $\begin{array}{l}\text { Streams et } \\
\text { al., Case } 1 \\
\text { [7] }\end{array}$ & Female & 44 & Alive & $\begin{array}{l}\text { Not } \\
\text { done }\end{array}$ & $\begin{array}{l}\text { Primary malignant melanoma of the left forearm underneath } \\
\text { an intact skin graft } 40 \text { years after having had a partial excision } \\
\text { and grafting of her GCMN }\end{array}$ & Not done & Not done \\
\hline $\begin{array}{l}\text { Tchernev } \\
\text { et al., Case } \\
1 \text { [8] }\end{array}$ & Female & 61 & Alive & $\begin{array}{l}\text { Not } \\
\text { done }\end{array}$ & Malignant melanoma of the occipital region (stage IIB) & Not done & Not done \\
\hline $\begin{array}{l}\text { Lalor et al., } \\
\text { Case } 1[35]\end{array}$ & \multirow[t]{2}{*}{ Female } & 8 & Alive & Normal & Nodular melanoma on the scalp & $\begin{array}{l}\text { Primary } \\
\text { tumor }\end{array}$ & $\begin{array}{l}\text { NRAS Q61R } \\
\text { mutation }\end{array}$ \\
\hline $\begin{array}{l}\text { De la Rosa } \\
\text { Carillo [9] }\end{array}$ & & $0 d$ & Died, $5 \mathrm{mo}$ & NCM & $\begin{array}{l}\text { Large, multilobular, pigmented lesion covering } 35 \% \text { of the } \\
\text { body, atypical melanocytic proliferation. Congenital melanoma. }\end{array}$ & $\begin{array}{l}\text { Several } \\
\text { biopsies }\end{array}$ & $\begin{array}{l}\text { NRAS Wild- } \\
\text { type, BRAF } \\
\text { Wild-type }\end{array}$ \\
\hline $\begin{array}{l}\text { Kinsler et } \\
\text { al., Case } 4 \\
\text { [22] }\end{array}$ & Male & 15,5 & Alive, $11 \mathrm{mo}$ & Normal & $\begin{array}{l}\text { Cutaneous, within largest CMN on the back of the scalp and } \\
\text { neck, metastatic to local lymph node at time of diagnosis }\end{array}$ & $\begin{array}{l}\text { Cutaneous } \\
\text { melanoma }\end{array}$ & $\begin{array}{l}\text { NRAS Wild- } \\
\text { type }\end{array}$ \\
\hline $\begin{array}{l}\text { Kinsler et } \\
\text { al., Case } 10 \\
\text { [22] }\end{array}$ & Male & $\begin{array}{l}\text { Not } \\
\text { known }\end{array}$ & $\begin{array}{l}\text { Death, age } \\
2,4 \text { years }\end{array}$ & Normal & $\begin{array}{l}\text { Lymph node groin, locally recurrent despite excision, local } \\
\text { metastasis }\end{array}$ & Not done & Not done \\
\hline $\begin{array}{l}\text { Kinsler et } \\
\text { al., Case } 12 \\
\text { [22] }\end{array}$ & Female & 6,5 & Death, 6 mo & Normal & $\begin{array}{l}\text { Cutaneous, within largest CMN, at the site of postnatal } \\
\text { resection of a benign congenital nodule, metastatic to local } \\
\text { lymph node at time of diagnosis }\end{array}$ & $\begin{array}{l}\text { Cutaneous } \\
\text { melanoma }\end{array}$ & $\begin{array}{l}\text { NRAS Q61K } \\
\text { mutation }\end{array}$ \\
\hline $\begin{array}{l}\text { Maguire et } \\
\text { al., Case } 2 \\
\text { [31] }\end{array}$ & Female & $7 \mathrm{mo}$ & Alive, 9 mo & $\begin{array}{l}\text { Not } \\
\text { done }\end{array}$ & $\begin{array}{l}\text { Cutaneous, on the groin site. A wide local excision was done. } \\
\text { At } 16 \text { months of age enlarged node in the groin, metastatic } \\
\text { melanoma }\end{array}$ & Not done & Not done \\
\hline \multicolumn{8}{|c|}{ Own experience } \\
\hline Case 1 & Male & $22 \mathrm{~d}$ & Alive & NCM & $\begin{array}{l}\text { Congenital cutaneous malignant melanoma of the lumbar- } \\
\text { sacral part }\end{array}$ & $\begin{array}{l}\text { Primary } \\
\text { tumor }\end{array}$ & $\begin{array}{l}\text { NRAS Wild- } \\
\text { type, BRAF } \\
\text { Wild-type }\end{array}$ \\
\hline Case 2 & Male & $5 \mathrm{mo}$ & Alive & Normal & $\begin{array}{l}\text { Congenital cutaneous malignant melanoma of the back of the } \\
\text { neck }\end{array}$ & $\begin{array}{l}\text { Primary } \\
\text { tumor }\end{array}$ & $\begin{array}{l}\text { NRAS Q61R } \\
\text { mutation }\end{array}$ \\
\hline
\end{tabular}


thickness of $1.5 \mathrm{~mm}$, without any symptoms of vessel invasion. According to immunohistochemical analysis, the tumor cells were positive for melanoma-specific markers Melan A and HMB45.

Ki67 is frequently used as an indicator of cell proliferation, and the Ki67 index of proliferation was $20-30 \%$ in tumor cells (Fig. 3). According to the literature, the Ki67 index is not a good marker for prognosis or confirming malignancy in cases of GCN burdened by melanoma. The melanoma sometimes might be a mitotically active proliferative nodule arising in a GCMN. This feature is worrisome when encountered in melanocytic lesions, but by itself, it should not trigger a diagnosis of melanoma in the absence of other histologic criteria of malignancy [33]. We used Ki67 as an additional marker. In Case 2, histopathology showed an epithelioid cell melanoma with 2 mitoses $/ \mathrm{mm}^{2}$, ulceration, satellites, and no vessel invasion (Fig. 6). The Breslow thickness (without satellites) was $2 \mathrm{~mm}$. The tumor node (melanoma satellite) was determined in subcutaneous tissue (Fig. 6).

Molecular analysis was performed on the biopsies obtained, and several genes that might play a role in GCMN development and malignant transformation were investigated. For patient M (Case 1), we evaluated the presence of somatic and germline mutations in the BRAF, NRAS, KIT, GNAQ, GNA11, MAP2K1/2, PDGFRA, RASA1, RAC1, MET, PTEN, AKT1, TP53, and TERT genes and somatic mutations in the GNAQ and GNA11 genes. Germline mutations in the $C D K N 2 A$ gene were also studied. Only non-pathogenic TP53 codon 72 Arg/Arg polymorphism was detected. For patient $\mathrm{L}$ (Case2), an analysis was performed to determine the somatic mutations in the BRAF, NRAS, KIT, GNAQ, GNA11, MAP2K1, and MAP2K2 genes and germline mutations in the $C D K N 2 A$ gene. Ultimately, only a Q61K mutation in the NRAS gene was found.

Mutations in the NRAS gene occur in $80-95 \%$ of giant CMNs [10, 34] and are considered one of the causes of CMN formation [22], although other factors are needed for malignant transformation [21]. In both of our cases, no specific mutation was identified that could account for the melanoma. Our colleagues previously published a clinical case of an 8-year-old girl with melanoma arising within a medium-size congenital nevus with NRAS Q61K mutation (case 5, Table 1) [35]. Kinsler et al. published the results of 25 years of experience at their center with melanoma in congenital melanocytic nevi, including the molecular characteristics of the tumor [23]. Among 12 patients with melanoma, 6 had melanoma in CNS, 3 had an unknown melanoma site, and 3 had cutaneous melanoma (Tables 1, 4-6). There were 9 patients who developed melanoma in the first 5 years of life, and 7 patients revealed a Q61K mutation in the NRAS gene. In 3 cases of cutaneous melanoma in one patient, Q61K was found as in our Case 2. When the diagnosis of cutaneous melanoma arising in a CMN is clinically suspected, an urgent biopsy should be performed (excision if possible) with histopathological examination by at least two experts. $N R A S$ and BRAF hotspot genotyping by sensitive methods are recommended to improve diagnostic accuracy and guide management.

The treatment of $\mathrm{CMN}$ is one of the most complicated areas of surgical and dermatologic oncology, and there are no commonly accepted standards to treat this lesion. It is not clear whether it is necessary to remove a CMN to reduce the risk of melanoma. In some reports, despite the almost complete removal of the $\mathrm{GCN}$, the surgery failed to prevent the development of malignant melanoma, and the role of surgical excision of GCN remains controversial [7, 36]. Although surgery does not reduce the risk of extracutaneous melanoma, the removal of melanocytic cells appears to reduce the risk of developing melanoma within the nevus. Some surgical options described for GCMN treatment include serial resection, skin grafts, and the use of tissue expanders [37].

Melanomas in the GCN usually develop before puberty in the first 5 years of life, as opposed to the small and medium nevi, where it routinely occurs after puberty $[4,5,38]$.

NCM is a rare complication that worsens the prognosis of GCN patients. NCM is neuromelanosis associated with $\mathrm{CMN}$, which describes melanocytic proliferation (benign or malignant and nodular or diffuse) within the leptomeninges and brain parenchyma [4-6, 9-11]. Kadonaga described NCM and redefined it as the presence of a CMN larger than $20 \mathrm{~cm}$ or multiple CMN (more than three) in association with meningeal melanosis or melanoma [39]. Our first case had NCM and malignant melanoma arising in a GCN larger than $20 \mathrm{~cm}$. Malignant melanoma and NCM most often occur in patients with CMN that have a diameter $>40 \mathrm{~cm}$, multiple satellite nevi, and a truncal location. Almost one-third of all patients with NCM have numerous medium-sized CMN.

For individuals at risk of NCM who are younger than 6 months old, gadolinium-enhanced screening MRI is recommended for long-term neurological observation [4]. Patients with neuromelanosis may be symptomatic or asymptomatic. In our case, MRI revealed the presence of melanin in the structures of the brain, which was performed despite an absence of neurological symptoms. Therefore, MRI evaluation should be performed for newborns with GCN (and especially with multiple satellite nevi).

The suggested work-up for a patient with CMN and a confirmed diagnosis of melanoma is the following: (1) full blood count and lactate dehydrogenase level; (2): CNS MRI with gadolinium contrast, whole-body positron emission tomography-computed tomography scan or computed tomography scans; (3) tissue sample for histopathology, NRAS, and BRAF hotspot genotyping and copy-number analysis (array CGH or SNP array or FISH). 
The genotyping may be important to therapy strategies including use of mitogen-activated protein kinase kinase (MEK) inhibitors in NRAS-mutated tumours [40].

\section{Conclusion}

Malignant melanoma arising in a GCNM is rare and poorly understood. Children with CMN should be included in a systemic follow-up from birth. The histopathology by at least two experts in the field and genetic analysis of driver mutations can help to differentiate melanoma from benign proliferative nodules in the skin. The most frequent genetic event in giant CMNs are NRAS mutations (up to 95\%), which was discovered in one of our cases. Given the rarity of the disease, it is important to accumulate new evidence concerning diagnostic features, prognosis, and clinical outcome.

\section{Abbreviations}

CCM: Congenital cutaneous melanoma; CM: Cutaneous melanoma; CMN: Congenital melanocytic nevus; GCN: Giant congenital nevus; MRI: Magnetic resonance imaging; NCM: neurocutaneous melanosis

\section{Acknowledgements}

None.

\section{Funding}

This work was supported by grant of the Russian Science Foundation (grant \# 14-35-00107).

\section{Availability of data and materials}

Not applicable.

\section{Authors' contributions \\ TSB and KVO designed the study and wrote the main parts of the report. TVN, MAE and ISA performed genetic analysis and wrote the coincident part of the report. YW performed the morphology and immunohistochemistry studies. KVO, MAE and TVN helped draft the manuscript. LNL, IAU, MBD, LVD and MDA revised the manuscript. This manuscript has been read and approved by all authors.}

\section{Ethics approval and consent to participate}

Parents of the patients provided informed consent. The study was approved by the Ethical Committee of the Federal State Budgetary Institution "N.N. Blokhin Medical Research Center of Oncology" of the Ministry of Health of the Russian Federation.

\section{Consent for publication}

Written informed consents for publication of their clinical details and/or clinical images were obtained from the parents of the patients. A copy of the consent forms is available for review by the Editor of this journal.

\section{Competing interests}

The authors declare that they have no competing interests.

\section{Publisher's Note}

Springer Nature remains neutral with regard to jurisdictional claims in published maps and institutional affiliations.

\section{Author details}

${ }^{1}$ Federal State Budgetary Institution, "N.N. Blokhin Medical Research Center of Oncology" of the Ministry of Health of the Russian Federation, 115478 Kashirskoye shosse, 24, Moscow, Russian Federation. ${ }^{2}$ Engelhardt Institute of Molecular Biology, Russian Academy of Sciences, Moscow, Russian Federation.
Received: 4 September 2018 Accepted: 10 February 2019

Published online: 19 February 2019

\section{References}

1. Ries L. Cancer Incidence and Survival among children and adolescents: United States SEER Program 1975-1995. Natl Cancer Institute, SEER Progr; 1999.

2. Desandes E, Clavel J, Berger C, Bernard J-L, Blouin P, de Lumley L, et al. Cancer incidence among children in France, 1990-1999. Pediatr Blood Cancer. 2004;43:749-57. https://doi.org/10.1002/pbc.20148.

3. Paschoal F. Nevo melanocítico congênito. An Bras Dermatol. 2002;77:649-56.

4. Price HN. Congenital melanocytic nevi: update in genetics and management. Curr Opin Pediatr. 2016:28:476-82.

5. Yun SJ, Kwon OS, Han JH, Kweon SS, Lee MW, Lee DY, et al. Clinical characteristics and risk of melanoma development from giant congenital melanocytic naevi in Korea: a nationwide retrospective study. $\mathrm{Br} J$ Dermatol. 2012;166:115-23. https://doi.org/10.1111/j.1365-2133.2011.10636.x.

6. Khashashneh I, Shatnawi M, Tawalbeh A, Alhaji MRM. Giant congenital hairy nevus on the scalp. Sudan J Med Sci. 2008;3:343-7.

7. Streams BN, Lio PA, Mihm MC, Sober AJ. A nonepidermal, primary malignant melanoma arising in a giant congenital melanocytic nevus 40 years after partial surgical removal. J Am Acad Dermatol. 2004:50:789-92. https://doi.org/10.1016/j.jaad.2003.09.023.

8. Tchernev G, Patterson JW, Bakardzhiev I, Lotti T, Lotti J, França K, et al. Late onset achromatic melanoma arising in a Giant congenital melanocytic nevus. Open Access Maced J Med Sci. 2017:5:533-4. https://doi.org/10.3889/oamims.2017.077.

9. de la Rosa Carrillo D, Vindenes H, Kinsler VA, Rønnestad A, Ringstad G, L-SO $M$, et al. Aggressive melanoma in an infant with congenital melanocytic nevus syndrome and multiple, NRAS and BRAF mutation-negative nodules. Pediatr Dermatol. 2018;35:e281-5. https://doi.org/10.1111/pde.13595.

10. Amir J, Metzker A, Nitzan M. Giant pigmented nevus occurring in one identical twin. Arch Dermatol. 1982;118:188-9.

11. Goodman RM, Caren J, Ziprkowski M, Padeh B, Ziprkowski L, Cohen BE. Genetic considerations in giant pigmented hairy naevus. Br J Dermatol. 1971;85:150-7.

12. de Wijn RS, Zaal LH, Hennekam RCM, van der Horst CMAM. Familial clustering of giant congenital melanocytic nevi. J Plast Reconstr Aesthetic Surg. 2010;63:906-13. https://doi.org/10.1016/j.bjps.2009.02.090.

13. Takayama H, La Rochelle WJ, Anver M, Bockman DE, Merlino G. Scatter factor/hepatocyte growth factor as a regulator of skeletal muscle and neural crest development. Proc Natl Acad Sci U S A. 1996;93:5866-71.

14. Takayama H, Nagashima Y, Hara M, Takagi H, Mori M, Merlino G, et al. Immunohistochemical detection of the c-met proto-oncogene product in the congenital melanocytic nevus of an infant with neurocutaneous melanosis. J Am Acad Dermatol. 2001;44:538-40. https://doi.org/10.1067/mjd.2001.112403.

15. Kos L, Aronzon A, Takayama H, Maina F, Ponzetto C, Merlino G, et al. Hepatocyte growth factor/scatter factor-MET signaling in neural crestderived melanocyte development. Pigment Cell Res. 1999;12:13-21.

16. Bauer J, Curtin JA, Pinkel D, Bastian BC. Congenital melanocytic nevi frequently harbor NRAS mutations but no BRAF mutations. J Invest Dermatol. 2007;127:179-82. https://doi.org/10.1038/sj.jid.5700490.

17. Dessars B, De Raeve LE, Morandini R, Lefort A, El Housni H, Ghanem GE, et al. Genotypic and gene expression studies in congenital melanocytic nevi: insight into initial steps of Melanotumorigenesis. J Invest Dermatol. 2009; 129:139-47. https://doi.org/10.1038/jid.2008.203.

18. Papp T, Pemsel H, Zimmermann R, Bastrop R, Weiss DG, Schivmann D. Mutational analysis of the N-ras, p53, p16 INK4a, CDK4, and MC1R genes in human congenital melanocytic naevi; 1999.

19. Dessars B, De Raeve LE, El HH, Debouck CJ, Sidon PJ, Morandini R, et al. Chromosomal translocations as a mechanism of BRAF activation in two cases of large congenital melanocytic nevi. J Invest Dermatol. 2007;127: 1468-70. https://doi.org/10.1038/sj.jid.5700725.

20. Ichii-Nakato N, Takata M, Takayanagi S, Takashima S, Lin J, Murata H, et al. High frequency of BRAFV600E mutation in acquired nevi and small congenital nevi, but low frequency of mutation in medium-sized congenital nevi. J Invest Dermatol. 2006;126:2111-8. https://doi.org/10.1038/sj.jid.5700366.

21. Phadke PA, Rakheja D, Le LP, Selim MA, Kapur P, Davis A, et al. Proliferative nodules arising within congenital melanocytic nevi. Am J Surg Pathol. 2011; 35:656-69. https://doi.org/10.1097/PAS.0b013e31821375ea.

22. Kinsler V, Bulstrode N, Calonje J, Chong W, Hargrave D, Jacques T, et al. Melanoma in congenital melanocytic naevi. Br J Dermatology Linked Comment. 2017;176:1131-43. https://doi.org/10.1111/bjd.15301. 
23. Kinsler VA, Abu-Amero S, Budd P, Jackson IJ, Ring SM, Northstone K, et al. Germline Melanocortin-1-receptor genotype is associated with severity of cutaneous phenotype in congenital melanocytic nevi: a role for MC1R in human fetal development. J Invest Dermatol. 2012;132:2026-32. https:/doi.org/10.1038/jid.2012.95.

24. Bittencourt FV, Marghoob AA, Kopf AW, Koenig KL, Bart RS. Large congenital melanocytic nevi and the risk for development of malignant melanoma and neurocutaneous melanocytosis. Pediatrics. 2000;106:736-41.

25. Emelyanova M, Ghukasyan L, Abramov I, Ryabaya O, Stepanova E, Kudryavtseva A, Sadritdinova A, Dzhumakova C, Belysheva T, Surzhikov S, Lyubchenko L, Zasedatelev A, Nasedkina T. Detection of BRAF, NRAS, KIT, GNAQ, GNA11 and MAP2K1/2 mutations in Russian melanoma patients using LNA PCR clamp and biochip analysis. Oncotarget. 2017;8(32):52304-20.

26. Krengel S, Hauschild A, Schafer T. Melanoma risk in congenital melanocytic naevi: a systematic review. Br J Dermatol. 2006;155:1-8. https://doi.org/10.1111/j.1365-2133.2006.07218.x.

27. Bastian $B C$, Olshen $A B$, LeBoit PE, Pinkel D. Classifying melanocytic tumors based on DNA copy number changes. Am J Pathol. 2003;163:1765-70. https://doi.org/10.1016/S0002-9440(10)63536-5.

28. Neuhold JC, Friesenhahn J, Gerdes N, Krengel S. Case reports of fatal or metastasizing melanoma in children and adolescents: a systematic analysis of the literature. Pediatr Dermatol. 2015;32:13-22. https://doi.org/10.1111/pde.12400.

29. Hale EK, Stein J, Ben-Porat L, Panageas KS, Eichenbaum MS, Marghoob AA, et al. Association of melanoma and neurocutaneous melanocytosis with large congenital melanocytic naevi-results from the NYU-LCMN registry. Br J Dermatol. 2005;152:512-7. https://doi.org/10.1111/j.1365-2133.2005.06316.x.

30. Pelin Cengiz F, Emiroglu N, Gulsel Bahali A, Su O, Onsun N. Malignant melanoma arising in congenital melanocytic nevi: clinical and dermoscopic challenges. Our Dermatol Online. 2017:8:34-6. https://doi.org/10.7241/ourd.20171.08.

31. Maguire CR, Livingston R, Phillips GE, Kimble RM. Giant congenital melanocytic nevi and malignant transformation: a case for early radical intervention. Pediatr Surg Int. 2017;33:823-7. https:/doi.org/10.1007/s00383-017-4095-2.

32. Mancianti ML, Clark WH, Hayes FA, Herlyn M. Malignant melanoma simulants arising in congenital melanocytic nevi do not show experimental evidence for a malignant phenotype. Am J Pathol. 1990;136:817-29.

33. Nguyen $\mathrm{TLT}$, Theos A, Kelly DR, Busam K, Andea A, Mitotically Active A. Proliferative nodule arising in a Giant congenital melanocytic nevus. Am J Dermatopathol. 2013; 35:e16-21. https://doi.org/10.1097/DAD.0b013e318265fe12

34. Charbel C, Fontaine RH, Malouf GG, Picard A, Kadlub N, El-Murr N, et al. NRAS mutation is the sole recurrent somatic mutation in large congenital melanocytic nevi. J Invest Dermatol. 2014;134:1067-74. https://doi.org/10.1038/jid.2013.429.

35. Lalor L, Busam K, Shah K. Prepubertal melanoma arising within a mediumsized congenital melanocytic nevus. Pediatr Dermatol. 2016;33:e372-4. https://doi.org/10.1111/pde.12961.

36. Lacoste C, Avril M, Frassati-Biaggi A, Dupin N, Chrétien-Marquet B, Mahé E, et al. Malignant melanoma arising in patients with a large congenital melanocytic Naevus: retrospective study of 10 cases with cytogenetic analysis. Acta Derm Venereol. 2015;95:686-90. https://doi.org/10.2340/00015555-2049.

37. Mutti L de A, Mascarenhas MRM, de PJMG, Golcman R, Enokihara MY, Golcman B. Giant congenital melanocytic nevi: 40 years of experience with the serial excision technique. An Bras Dermatol. 2017:92:256-9. https://doi.org/10.1590/abd1806-4841.20174885.

38. Zembowicz A, Phadke PA. Blue nevi and variants: an update. Arch Pathol Lab Med. 2011;135:327-36. https://doi.org/10.1043/2009-0733-RA.1.

39. DeDavid M, Orlow SJ, Provost N, Marghoob AA, Rao BK, Wasti Q, et al. Neurocutaneous melanosis: clinical features of large congenital melanocytic nevi in patients with manifest central nervous system melanosis. J Am Acad Dermatol. 1996;35:529-38.

40. Kinsler VA, O'Hare P, Jacques T, Hargrave D, Slater O. MEK inhibition appears to improve symptom control in primary NRAS-driven CNS melanoma in children. Br J Cancer. 2017;116:990-3. https://doi.org/10.1038/bjc.2017.49.

Ready to submit your research? Choose BMC and benefit from:

- fast, convenient online submission

- thorough peer review by experienced researchers in your field

- rapid publication on acceptance

- support for research data, including large and complex data types

- gold Open Access which fosters wider collaboration and increased citations

- maximum visibility for your research: over $100 \mathrm{M}$ website views per year

At BMC, research is always in progress.

Learn more biomedcentral.com/submissions 